\title{
Influence of Porosity in Quantitative Analysis of Heavy Mineral Placer Deposits
}

Joevivek V ${ }^{1,2 *}$, Chandrasekar $\mathbf{N}^{2}$ and Shree Purniema $\mathbf{K}^{1}$

${ }^{1}$ Akshaya College of Engineering and Technology, India

${ }^{2}$ Centre for Geo Technology, Manonmaniam Sundaranar University, India

Submission: December 08, 2017; Published: March 01, 2018

*Corresponding author: Joevivek V, Akshaya College of Engineering and Technology, Kinathukadavu, Coimbatore- 642 109, India,

Email: vjoevivek@gmail.com

\section{Abstract}

The Heavy mineral analysis of the beach sediment is one of the finest ways to interpret the presence of the placer deposits in the coast. The point counting method is a widely used technique, which is employed for the quantitative analysis of heavy minerals. Nevertheless, this method is not applicable in case of large scale volumetric or spatial investigations as the surficial sediments occupy an inaccurate space due to its irregular grain size. Therefore, porosity is an important feature that has to be considered for the analyzing the quantitative distribution of the placer minerals present in the surface sediments. This paper highlights the effect of porosity in the heavy mineral distribution with respect to the grain size. The outcome from this research helps to enhance the results in quantitative analysis of heavy minerals.

Keywords: Heavy minerals, porosity, beach, sediments, grain size

Heavy mineral analysis

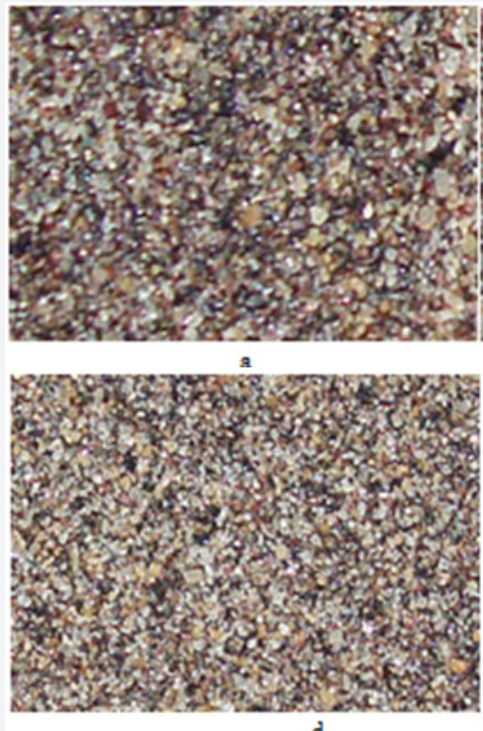

d

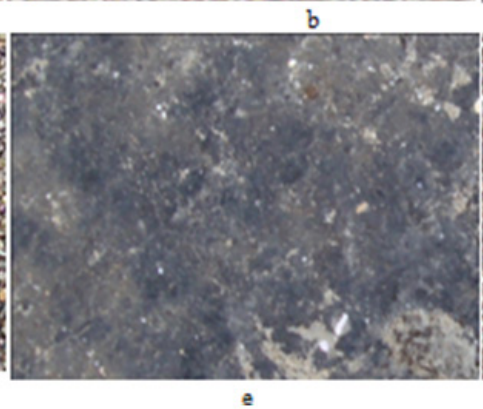

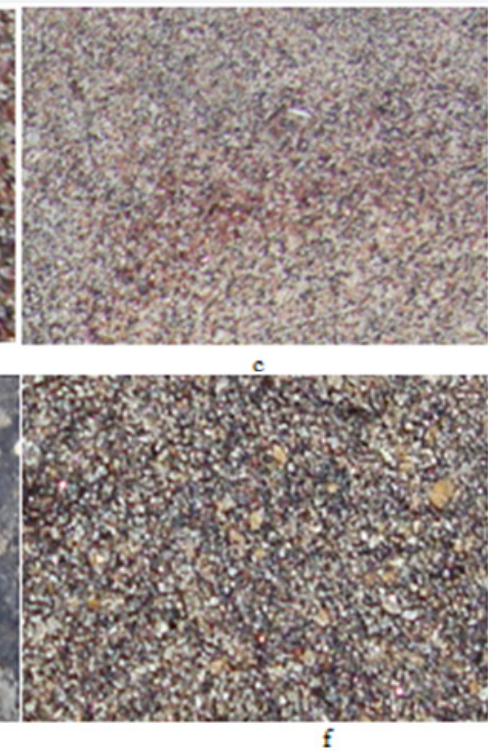

Figure 1(a-f): Different kinds of heavy mineral placer distribution at Kottucherrymedu beach. a) High concentration of medium size placer deposits, b) Placer deposits in the form of medium to fine sand, c) Garnet fractions, d) Mixture of placer deposits, e) Laminated black sand with magnetite and illmenite, f) Placer deposits with highly concentrate black sands.

Quantitative investigation of mineral assemblages was initiated by the work of Fleet and Smithson [1], who introduced the method of grain counting to develop the estimation of relative mineral frequencies. This method provides information of the relative percentage of each mineral present in the sample [2]. In this particular research, field site is chosen along the 
Kottucherrymedu beach (Latitude: $10.964 \mathrm{~N}$ and Longitude: 79.854E), central Tamil Nadu coast, India. The heavy mineral assemblage of the study region is controlled by the distribution of different type of minerals. Although the assemblage consists of various minerals, few selective placer minerals like magnetite, ilmenite, garnet, zircon and rutile [2-6] are the dominant minerals that are considered for this purpose. Totally 100 samples were collected at tide, berm and backshore region. The photographic view of different location, from which the sample is obtained, is shown in Figure 1. These samples were treated and categorized as medium $(+40$ to +60 ASTM $)$, fine $(+60$ to +120 ASTM $)$ and very fine $(+120$ to +230 ASTM) fractions. A high-density liquid i.e., Bromoform (specific gravity is 2.89 and molecular weight $252.73 \mathrm{~g} / \mathrm{mol}$ ) is utilized for separation of heavy and light fractions. Further, the fraction of heavies is identified with the help of the microscope image counting method.

\section{Porosity Estimation Using Petrographic Image Analysis (PIA)}

Petrographic image analysis (PIA) is frequently used by geoscientists in a wide variety of petrographic applications including textural, mineralogical, fabric and porosity analysis [7-9]. A study of 150 thin sections of placer fractions with three different sizes (medium, fine and very fine) were prepared for the present investigation. Segmentation method is widely used to segregate the pores to improve the separation between pores and solid grains. This method can provide the total porosity; also it provides a highly accurate result in all the rocks except those that have an extremely isotropic/anisotropic pore structure. However, the advantage of this process is that, the pore types and the micro-textural properties of the grains can be determined during the process. A circular face with uniform magnification $(400 \mu \mathrm{m})$ was fixed in the imaging microscopy. The percentage of void space is evaluated from the microscopic images using pixel counting method.

\section{Influence of Porosity in Heavy Mineral Quantity}

The microscopic analysis shows respective fractions and its pore space for estimating total pore space present in the samples. Microscopic analysis of mineral distribution and its porosity value is presented in Table 1. Microscopic observation exposed that the porosity of garnet is much higher than that of other minerals. Garnet fractions is composed of angular/subangular structure hence, the particle reveals high porosity with less compaction nature. Rhombohedral crystalline structure of ilmenite has sub-angular and angular structure, obtains the porosity value with respect to crystalline structure and size of the particle distribution. The mixed fractions of the deposits are seen as Ilmenite-hematite, Ilmenite-leucoxene and magnetitehematite minerals etc. It exhibits magnetic property when these fractions are mixed with other mineral fractions based on excessive electron/proton present in the crystalline structure. Zircon fractions show rounded and angular grains with medium pore space. The percentage of these mineral distribution is also compared with the results of normal counting method (Table 2). The results obtained based on the porosity value, revealed lesser percentage when compared to the normal counting method. The medium sized garnet showed a higher porosity value while ilmenite showed a lower porosity value. It is observed that, the porosity value decreases when the sediment size decreases. On the whole, the outcome revealed the porosity value of the moreangular grains is larger than those that are sub-spherical.

Table 1: Percentage of porosity distribution present in the heavy minerals.

\begin{tabular}{|c|c|c|c|c|c|c|}
\hline \multirow{2}{*}{ Minerals } & \multicolumn{2}{|c|}{ Medium } & \multicolumn{2}{c|}{ Fine } & \multicolumn{2}{c|}{ Very Fine } \\
\cline { 2 - 8 } & Heavy mineral (\%) & Porosity (\%) & Heavy mineral (\%) & Porosity (\%) & Heavy mineral (\%) & Porosity (\%) \\
\hline Magnetite & 72 & 28 & 83 & 17 & 88 & 12 \\
\hline Ilmenite & 81 & 19 & 85 & 15 & 89 & 71 \\
\hline Garnet & 62 & 38 & 67 & 33 & 79 & 13 \\
\hline Zircon & 76 & 24 & 84 & 16 & 87 & 11 \\
\hline Rutile & 75 & 25 & 83 & 17 & 89 & 13 \\
\hline
\end{tabular}

Table 2: The comparison results of normal counting and porosity based microscopic counting.

\begin{tabular}{|c|c|c|c|c|c|c|}
\hline \multirow{2}{*}{ Grain Size } & \multicolumn{6}{|c|}{ Heavy Minerals } \\
\hline & Magnetite & Ilmenite & Garnet & Zircon & Rutile & Others \\
\hline \multicolumn{7}{|c|}{ Without porosity } \\
\hline Medium & 6.89 & 20.66 & 16.53 & 18.95 & 0.88 & 36.09 \\
\hline Fine & 13.18 & 29.46 & 22.23 & 5.54 & 1.85 & 27.74 \\
\hline Very fine & 21.13 & 32.63 & 18.75 & 5.12 & 2.12 & 20.25 \\
\hline \multicolumn{7}{|c|}{ With porosity } \\
\hline Medium & 4.96 & 16.73 & 10.25 & 14.4 & 0.66 & 53 \\
\hline Fine & 10.94 & 25.04 & 14.89 & 4.65 & 1.54 & 42.94 \\
\hline Very fine & 18.59 & 29.04 & 14.81 & 4.45 & 1.87 & 31.24 \\
\hline
\end{tabular}




\section{References}

1. Fleet WF, Smithson F (1928) On the occurrence of dark apatite in some British rocks. Geological Magazine 65: 6-8.

2. Gert Jan Weltje, Hilmar von Eynatten (2004) Quantitative provenance analysis of sediments: review and outlook. Sedimentary Geology 171(1-4): $1-11$.

3. Joevivek V, Chandrasekar N, Saravanan S, Anandakumar H, Thanushkodi $\mathrm{K}$, et al. (2017) Spatial and temporal correlation between beach and wave processes: Implications for bar - berm sediment transition. Frontiers of Earth Science 1-12.

4. Joevivek V, Chandrasekar N (2014) Seasonal impact on beach morphology and the status of heavy mineral deposition - central Tamil Nadu coast, India. Journal of Earth System Science 123(1): 135-149.

5. Joevivek V, Chandrasekar N (2016) ONWET: A Simple Integrated Tool for Beach Morphology and Wave Dynamics Analysis. Marine Georesources and Geotechnology 34(6): 581-593.
6. Joevivek V, Chandrasekar N (2017) Data on nearshore wave process and surficial beach deposits, central Tamil Nadu coast, India. Data in Brief 13: 306-311.

7. Ehrlich R, Crabtree SJ, Horkowitz KO, Horkowitz JP (1991) Petrography and reservoir physics 1: objective classification of reservoir porosity. American Association of Petroleum Geologists Bulletin 75(10): 15471562.

8. McCreesh CA, Ehrlich R, Crabtree SJ (1991) Petrography and reservoir physics 2: relating thin section porosity to capillary pressure, the Association Between Pore Types and Throat Size (1). American Association of Petroleum Geologists Bulletin 75(10): 1563-1578.

9. Ehrlich R, Crabtree SJ, Kenneedy SK, Cannon RL (1984) Petrographic image analysis 1-analysis of reservoir pore complexes. Journal of Sedimentary Petrology 54(4): 1365-1378.

\section{Your next submission with Juniper Publishers} will reach you the below assets

- Quality Editorial service

- Swift Peer Review

- Reprints availability

- E-prints Service

- Manuscript Podcast for convenient understanding

- Global attainment for your research

- Manuscript accessibility in different formats ( Pdf, E-pub, Full Text, Audio)

- Unceasing customer service

Track the below URL for one-step submission https://juniperpublishers.com/online-submission.php 